\title{
OUTPUT EFFECTS OF INFLATION WITH FIXED PRICE- AND QUANTITY-ADJUSTMENT COSTS
}

\author{
LEIF DANZIGER
}

\author{
CESIFO WORKING PAPER NO. 1538 \\ CAtegory 5: Fiscal Policy, Macroeconomics and Growth \\ SEPTEMBER 2005
}

An electronic version of the paper may be downloaded
- from the SSRN website: $\quad$ www.SSRN.com
- from the CESifo website: $\quad$ www.CESifo-group.de 


\title{
OUTPUT EFFECTS OF INFLATION WITH FIXED PRICE- AND QUANTITY-ADJUSTMENT COSTS
}

\begin{abstract}
With fixed costs of price and quantity adjustment, output effects of inflation depend on the elasticity of the firm's marginal real revenue. If the elasticity always exceeds minus unity, then output decreases with inflation, while if the elasticity is always less than minus unity, then output increases with inflation. In the special case that the elasticity always equals minus unity, then output is independent of inflation. This is the case if demand is derived from a logquadratic utility function.
\end{abstract}

JEL Code: E31.

\author{
Leif Danziger \\ Department of Economics \\ Ben-Gurion University \\ Beer-Sheva 84105 \\ Israel \\ danziger@bgu.ac.il \\ and \\ Department of Economics \\ Central European University \\ Budapest 1051 \\ Hungary \\ danziger@ceu.hu
}

The support of CES (Center for Economic Studies at the University of Munich) is gratefully acknowledged. 


\section{Introduction}

There is convincing evidence that fixed costs of price adjustment may be large. Thus, Levy et al. (1997) and Zbaracki et al. (2004) find the cost to be $0.7 \%$ and $1.22 \%$ of a firm's revenue, respectively. In the presence of fixed costs of price adjustment, a monopolistic firm does not adjust its nominal price continuously, with the result that the real price and output generally deviate from their static monopoly level. At low inflation rates, the average output is higher than the static monopoly output if there is positive discounting (Danziger, 1988), and depends on higher order derivatives of the profit and demand functions if there is no discounting (Benabou and Konieczny, 1994). ${ }^{1}$

Most of the literature assume that only price adjustments are costly, while output can be continuously adjusted. However, Bresnahan and Ramey (1994) document that there may be very large fixed costs of adjusting quantities, and many papers show that adjusting labor and capital inputs involves significant fixed costs. ${ }^{2}$ Such costs may derive from the loss of organizational capital (Baily et al., 2001 and Jovanovic and Rousseau, 2001), as well as from job protection rules, severance pay, and legal and administrative complications.

In a framework with both price- and quantity-adjustment costs, Andersen (1995) and Andersen and Toulemonde (2004) demonstrate that only intermediate-size shocks - but not large or small shocks - may affect output. For a constant inflation rate, Danziger (2001) shows that a firm's permanent production decreases with inflation at low inflation rates if discounting is positive, and Danziger and Kreiner (2002) that output capacity decreases with inflation if the elasticity of demand is constant and there is no discounting.

The purpose of this paper is to provide a simple general characterization of the output effects of a constant inflation rate if both price and quantity adjustments involve fixed costs. It is assumed that quantity adjustments are at least as costly as price adjustments, which

\footnotetext{
${ }^{1}$ See also Rotemberg (1983), Kuran (1986), Naish (1986), Benabou (1988), and Konieczny (1990).

${ }^{2}$ For the cost of adjusting labor, see Davis and Haltiwanger (1992), Hamermesh (1989), Caballero et al. (1997), and Abowd and Kramarz (2003). For the cost of adjusting capital, see Doms and Dunne (1998), Cooper et al. (1999), and Nilsen and Schiantarelli (2003).
} 
implies that production is kept constant at a permanent level. ${ }^{3}$ The firm keeps its nominal price unchanged in periods of equal length, and adjusts the nominal price so that the initial real price is the same in each period. Thus, the firm's optimal strategy consists of the initial real price, the duration of the periods with unchanged nominal price, and the permanent level of production. It is proved that, in the absence of discounting, the effect of inflation on the permanent production is fully determined by the elasticity of the firm's marginal real revenue: output decreases with inflation if the elasticity is always greater than minus unity, increases with inflation if the elasticity is always less than minus unity, and is unaffected by inflation if the elasticity is always equal to minus unity. The latter occurs if demand is derived from a log-quadratic utility function.

The explanation for this is that the firm can only sell part of the permanent production at the beginning of a period when the real price is high, but all of it at the end of a period when the real price is low. A higher inflation rate is associated with a higher real price, and hence lower sales, at the beginning of a period, as well as with a lower real price at the end of the period, when the firm anyway sells all it produces. The smaller the marginal real revenue at the initial real price, the less pronounced is the negative effect on the real revenue of lower sales at the beginning of the period; accordingly, for a given inflationinduced increase in the real price at the beginning of a period, the smaller is the absolute value of the inflation-induced decrease in the real price at the end of a period, which tends to decrease the permanent production.

Additionally, a higher real price at the beginning of a period and a lower real price at the end of the period imply a smaller average marginal real revenue in the period. Hence, a smaller loss of average marginal real revenue from an increase in the initial real price relative to the loss of average marginal real revenue from a decrease in the terminal real price, also leads to a smaller absolute value of the decrease of the real price at the end of the period for a given increase in the real price at the beginning of a period, which further tends to

\footnotetext{
${ }^{3}$ See Danziger (2001). Production clearly reacts to shocks and may even vary more than prices over the business cycle. However, the present model does not include shocks, the focus being on a fully anticipated, constant rate of inflation.
} 
decrease the permanent production.

The effect of inflation on output therefore depends on how fast the marginal real revenue decreases with demand. As shown in the paper, if the marginal real revenue is less than inversely proportional to demand, in which case the elasticity of the marginal real revenue always exceeds minus unity, then output decreases with inflation. Conversely, if the marginal real revenue is more than inversely proportional to demand, in which case the elasticity of the marginal real revenue is always less than minus unity, then output increases with inflation. If the marginal real revenue is inversely proportional to demand, so that the elasticity of the marginal real revenue always equals minus unity, then output is invariant to inflation.

Several recent studies have found that the co-movement between output and prices is typically negative in the long run (Kydland and Prescott, 1990; Cooley and Ohanian, 1991; Fiorito and Kollintzas, 1994; Den Haan, 2000; and Den Haan and Summer, 2004). Within the framework of the present model, this indicates that the empirically relevant case is that the elasticity of the marginal real revenue always exceeds minus unity. ${ }^{4}$ This is satisfied, among others, by the important class of demand functions exhibiting a constant price elasticity less than minus unity.

\section{The Model}

Consider a monopolistic firm producing a single perishable. The stationary demand function is $D\left(z_{t}\right)$, where $z_{t}$ denotes the real price at time $t$, and $z_{t} D^{\prime}\left(z_{t}\right) / D\left(z_{t}\right)<-1$.

The inflation rate is a constant $\mu>0$. The firm sets its output and nominal price, and adjusting either involves a fixed cost. Quantity adjustments are at least as expensive as price adjustments, so the firm keeps its output constant at a permanent level, while adjusting the

\footnotetext{
${ }^{4}$ While this paper analyzes the output behavior of a single firm, the empirical findings refer to the aggregate output of all firms. However, with similar assumptions as in Danziger (2001), the partial-equilibrium framework can be embedded in a general-equilibrium model with a continuum of firms producing differentiated goods and facing demand functions that depend on only the real price charged for the firm's good. The aggregate production in the economy will then depend on the inflation rate in the same way as the output of a single firm studied in this paper. See also Chari, Kehoe and McGrattan (2000) who study the output consequences of monetary shocks in a model with staggered price setting.
} 
nominal price at equally spaced intervals. The initial real price is the same in all periods with unchanged nominal price.

Let $Y$ denote the permanent production and $C(Y), C^{\prime}(Y)>0$, the real cost of production. The real price at which demand equals production is $z_{Y} \equiv D^{-1}(Y)$. At higher real prices, the firm sells less than it produces, while at lower real prices, the firm could sell more than it produces. The firm's instantaneous real profit from production at time $t$ is

$$
\begin{cases}z_{t} D\left(z_{t}\right)-C(Y) & \text { if } z_{t} \geq z_{Y} \\ z_{t} Y-C(Y) & \text { if } \quad z_{t}<z_{Y} .\end{cases}
$$

If $S$ is the initial real price in a period with a constant nominal price, then $z_{\tau}=S e^{-\mu \tau}$ is the real price after $\tau$ of the period has elapsed, and $T_{Y} \equiv(1 / \mu) \ln \left(S / z_{Y}\right)$ is the time taken for the real price to decrease $z_{Y}$. It is assumed that $0<T_{Y}<T$, where $T$ is the duration of the period. If $c$ is the fixed real cost of a price adjustment incurred at the beginning of the period, the average real profit in a period is

$$
V \equiv \frac{1}{T}\left[\int_{0}^{T_{Y}} S e^{-\mu \tau} D\left(S e^{-\mu \tau}\right) d \tau+\int_{T_{Y}}^{T} S e^{-\mu \tau} Y d \tau-c\right]-C(Y) .
$$

The first integral is the total real revenue when the firm sells less than it produces, and the second integral is the total real revenue when the firm sells everything it produces.

There is no discounting, and the firm chooses $S, T$, and $Y$ to maximize the average real profit. The first-order conditions are

$$
\begin{aligned}
\frac{\partial V}{\partial S} & =\frac{1}{T}\left[\int_{0}^{T_{Y}} e^{-\mu \tau} D\left(S e^{-\mu \tau}\right) d \tau+\int_{0}^{T_{Y}} S e^{-2 \mu \tau} D^{\prime}\left(S e^{-\mu \tau}\right) d \tau+\int_{T_{Y}}^{T} e^{-\mu \tau} Y d \tau\right]=0, \\
\frac{\partial V}{\partial T} & =\frac{1}{T}[s Y-C(Y)-V]=0, \\
\frac{\partial V}{\partial Y} & =\frac{1}{T} \int_{T_{Y}}^{T} S e^{-\mu \tau} d \tau-C^{\prime}(Y)=0,
\end{aligned}
$$

where $s \equiv S e^{-\mu T}$ is the terminal real price. 
These can be rewritten $\operatorname{as}^{5}$

$$
\begin{aligned}
S D(S)-s Y & =0, \\
s Y-C(Y)-V & =0, \\
\frac{1}{T} \int_{T_{Y}}^{T} S e^{-\mu \tau} d \tau-C^{\prime}(Y) & =0 .
\end{aligned}
$$

Condition (1) shows that the initial and terminal real revenues are equal, or equivalently, that the initial and terminal real profits from production are equal. Condition (2) shows that the terminal real profit from production equals the average real profit (which takes the fixed cost of price adjustment into account). Condition (3) shows that the average marginal real revenue equals the marginal real cost. It is assumed that conditions (1)-(3) yield a unique maximum and that the average real profit is positive.

\section{Inflation and Permanent Production}

To determine how the permanent production varies with the inflation rate, conditions (1)-(3) are totally differentiated with respect to $\mu$, which yields

$$
\frac{d Y}{d \mu}=\frac{\left[\phi D(S)-C^{\prime}(Y) Y\right] c S}{\left.\left\{\phi s\left[Y / D^{\prime}\left(z_{Y}\right)+s-2 C^{\prime}(Y)+Y C^{\prime \prime}(Y) \mu T\right]+S C^{\prime}(Y)^{2}\right)\right\} Y \mu T}
$$

where

$$
\phi \equiv \frac{D(S)}{D^{\prime}(S)}+S
$$

${ }^{5}$ Partially integrating $\int_{0}^{T_{Y}} S e^{-2 \mu \tau} D^{\prime}\left(S e^{-\mu \tau}\right) d \tau$ yields

$$
\int_{0}^{T_{Y}} S e^{-2 \mu \tau} D^{\prime}\left(S e^{-\mu \tau}\right) d \tau=-\int_{0}^{T_{Y}} e^{-\mu \tau} D\left(S e^{-\mu \tau}\right) d \tau+\frac{1}{\mu}\left[D(S)-e^{-\mu T_{Y}} D\left(z_{Y}\right)\right] .
$$

Hence,

$$
\begin{aligned}
\frac{\partial V}{\partial S} & =\frac{1}{T}\left\{\frac{1}{\mu}\left[D(S)-e^{-\mu T_{Y}} D\left(z_{Y}\right)\right]+\int_{T_{Y}}^{T} e^{-\mu \tau} Y d \tau\right\} \\
& =\frac{1}{\mu T}\left[D(S)-e^{-\mu T} Y\right] \\
& =\frac{1}{\mu T S}[S D(S)-s Y] .
\end{aligned}
$$


is the marginal real revenue at the initial real price.

Since the denominator of $d Y / d \mu$ is positive from the second-order condition, $d Y / d \mu$ has the same sign as

$$
\phi D(S)-C^{\prime}(Y) Y
$$

To understand this result, note that as the inflation rate increases, the initial real price increases and the terminal real price decreases. The firm sells less than it produces when real prices are high, but all it produces when real prices are low, so a higher $S$ reduces output, while a lower $s$ increases output. Hence, the overall effect of inflation on the permanent production depends on whether the output response of the higher $S$ or the lower $s$ dominates.

The smaller the marginal real revenue at the initial real price, the less the real revenue at the beginning of a period with a constant nominal price increases in $D(S)$; the lower is therefore the loss of initial real revenue from an increase in $S$ relative to the loss of terminal real revenue from a decrease in $s$. Accordingly, the smaller the marginal real revenue at the initial real price, the less $s$ decreases for a given increase in $S$, which tends to make $Y$ a decreasing function of inflation.

The increase in $S$ and the decrease in $s$ reduce not only the initial and terminal real revenues, however, but also the average marginal revenue in a period. Since a smaller loss of average marginal real revenue from an increase in $S$ relative to the loss from a decrease in $s$ also causes a smaller decrease in $s$ for a given increase in $S$, this too tends to make $Y$ an decreasing function of inflation.

Specifically, expression (4) shows that $Y$ decreases with inflation if the marginal real revenue decreases sufficiently slowly with demand that $\phi D(S)$ is an increasing function of $D(S)$. Put differently, $Y$ decreases with inflation if the marginal real revenue always changes less than inversely proportional with demand, or equivalently, if the elasticity of the marginal real revenue always exceeds minus unity. Conversely, $Y$ increases with inflation if the marginal real revenue decreases sufficiently fast with demand that $\phi D(S)$ is a decreasing function of $D(S)$; that is, if the marginal real revenue always changes more than inversely proportional with demand, or equivalently, if the elasticity of the real revenue is always 
less than minus unity. Finally, $Y$ is constant and equal to the static monopoly output for all inflation rates if the marginal real revenue is inversely proportional to demand, making $\phi D(S)$ constant; this occurs if the elasticity of the real revenue always equals minus unity.

\section{An Example}

In this example, depending on the value of a constant, the permanent production either decreases with inflation, increases with inflation, or is independent of inflation.

Let the inverse demand function be

$$
z_{t}=\frac{\alpha \ln D\left(z_{t}\right)+\beta}{D\left(z_{t}\right)}+\gamma
$$

where $\alpha>0$ and $\gamma<C^{\prime}(0), \beta$ any real number, and $z_{t} \leq \alpha e^{\beta / \alpha-1} \cdot{ }^{6}$ The marginal real revenue is $\alpha / D\left(z_{t}\right)+\gamma$, and its elasticity $-1 /\left[1+\gamma D\left(z_{t}\right) / \alpha\right]$. Thus, the marginal real revenue is inversely proportional to demand if $\gamma=0$. Furthermore, since the demand curve moves up with $\gamma$ without changing its slope, the marginal real revenue, and hence also its elasticity, for a given real price increases with $\gamma$.

If $\gamma>0$, the elasticity of the marginal real revenue always exceeds minus unity: the permanent production decreases with inflation and is always less than the static monopoly output. $^{7}$ If $\gamma<0$, the opposite is the case. If $\gamma=0$, in which case the inverse demand function reflects a log-quadratic utility function, the elasticity of the marginal real revenue is always minus unity: the permanent production is independent of inflation and always equals the static monopoly output. is

${ }^{6}$ A quasilinear utility function of good $y$ and numeraire good $m$ underlying this inverse demand function

$$
\frac{1}{2} \alpha(\ln y)^{2}+\beta \ln y+\gamma y+m,
$$

which is $\log$-quadratic in $y$ if $\gamma=0$. The utility is increasing and concave in $y$ for $(\alpha \ln y+\beta) / y+\gamma>0$ and $y \geq e^{1-\beta / \alpha}$.

${ }^{7}$ As mentioned in the introduction, the condition that the elasticity of the marginal real revenue always exceeds minus unity is also satisfied by all demand functions that have a constant price elasticity less than minus unity. 


\section{Conclusion}

This paper examines how the permanent production varies with inflation when there are fixed price- and quantity-adjustment costs, showing that it is determined by the elasticity of the marginal real revenue. If the elasticity always exceeds minus unity, then output decreases with inflation, whereas if the elasticity is always less than minus unity, then output increases with inflation. In the special case that the elasticity always equals minus unity, then output is independent of inflation. This is the case if demand is derived from a log-quadratic utility function. 


\section{References}

Abowd, J. M. and Kramarz, F. "The Costs of Hiring and Separations." Labour Economics 10, 2003, 499-530.

Andersen, T. M. "Adjustment Costs and Price and Quantity Adjustment." Economics Letters 47, 1995, 343-49.

Andersen, T. M. and Toulemonde, E. "Adapting Prices or Quantities in the Presence of Adjustment Costs." Journal of Money, Credit and Banking 36, 2004, 177-96.

Baily, M. N., Bartelsman, E. J., and Haltiwanger, J. "Labor Productivity: Structural Change and Cyclical Dynamics." Review of Economics and Statistics 83, 2001, 420-33.

Benabou, R. "Search, Price Setting and Inflation." Review of Economic Studies 55, 1988, 353-76.

Benabou, R. and Konieczny, J. D. "On Inflation and Output with Costly Price Changes: A Simple Unifying Result." American Economic Review 84, 1994, 290-97.

Caballero, R. J., Engel, E. M. R. A., and Haltiwanger, J. C. "Aggregate Employment Dynamics: Building from Microeconomic Evidence." American Economic Review 87, 1997, $115-37$.

Chari, V. V., Kehoe, P. J., and McGrattan, E. R. "Sticky Price Models of the Business Cycle: Can the Contract Multiplier Solve the Persistence Problem?" Econometrica 68, 2000, 1151-1179.

Cooley, T. F. and Ohanian, L. E. "The Cyclical Behavior of Prices." Journal of Monetary Economics 28, 1991, 25-60.

Cooper, R., Haltiwanger, J., and Power, L. "Machine Replacement and the Business Cycle: Lumps and Bumps." American Economic Review 89, 1999, 921-46.

Danziger, L. "Costs of Price Adjustment and the Welfare Economics of Inflation and Disinflation." American Economic Review 78, 1988, 633-46.

Danziger, L. "Output and Welfare Effects of Inflation with Costly Price and Quantity Adjustments." American Economic Review 91, 2001, 1608-20. 
Danziger, L. and Kreiner, C. T. "Fixed Production Capacity, Menu Cost and the OutputInflation Relationship." Economica 69, 2002, 433-44.

Davis, S. J. and Haltiwanger, J. "Gross Job Creation, Gross Job Destruction, and Employment." Quarterly Journal of Economics 10\%, 1992, 819-63.

Den Haan, W. J. "The Comovement between Output and Prices." Journal of Monetary Economics 46, 2000, 3-30.

Den Haan, W. J. and Sumner, S. W. "The Comovement between Real Activity and Prices in the G7." European Economic Review 48, 2004, 1333-1347.

Doms, M., and Dunne, T. "Capital Adjustment Patterns in Manufacturing Firms." Review of Economic Dynamics 1, 1998, 409-29.

Fiorito, R. and Kollintzas, T. "Stylized Facts of Business Cycles in the G7 from a Real Business Cycle Perspective." European Economic Review 38, 1994, 235-269.

Hamermesh, D. S. "Labor Demand and the Structure of Adjustment Costs." American Economic Review 79, 1989, 674-89.

Jovanovic, B. and Rousseau, P. L. "Vintage Organization Capital." NBER Working Paper No. 8166, 2001.

Konieczny, J. D. "Inflation, Output and Labour Productivity when Prices are Changed Infrequently." Economica 57, 1990, 201-18.

Kuran, T. "Price Adjustment Costs, Anticipated Inflation, and Output." Quarterly Journal of Economics 101, 1986, 407-18.

Kydland, F. E. and Prescott, E. C. "Business Cycles: Real Facts and a Monetary Myth." Quarterly Review, Federal Reserve Bank of Minneapolis, 1990, 3-18.

Levy, D., Bergen, M., Dutta, S., and Venable, R. "On the Magnitude of Menu Costs: Direct Evidence from Large U. S. Supermarket Chains." Quarterly Journal of Economics 112, 1997, 791-825.

Naish, H. F. "Price Adjustment Costs and Output-Inflation Trade-off." Economica 53, 1986, 219-30. 
Nilsen, O. A. and Schiantarelli, F. "Zeros and Lumps in Investment: Empirical Evidence on Irreversibilities and Nonconvexities." Review of Economics and Statistics 85, 2003, 1021-37.

Rotemberg, J. J. "Aggregate Consequences of Fixed Costs of Price Adjustment." American Economic Review 73, 1983, 433-36.

Zbaracki, M.J., Ritson, M., Levy, D., Dutta, S., and Bergen, M. "Managerial and Customer Costs of Price Adjustment: Direct Evidence from Industrial Markets." Review of Economics and Statistics 86, 2004, 514-33. 


\section{CESifo Working Paper Series}

(for full list see www.cesifo-group.de)

1473 Kai A. Konrad, Silent Interests and All-Pay Auctions, May 2005

1474 Ingo Vogelsang, Electricity Transmission Pricing and Performance-Based Regulation, May 2005

1475 Spiros Bougheas and Raymond Riezman, Trade and the Distribution of Human Capital, June 2005

1476 Vesa Kanniainen, Seppo Kari and Jouko Ylä-Liedenpohja, The Start-Up and Growth Stages in Enterprise Formation: The "New View" of Dividend Taxation Reconsidered, June 2005

1477 M. Hashem Pesaran, L. Vanessa Smith and Ron P. Smith, What if the UK had Joined the Euro in 1999? An Empirical Evaluation Using a Global VAR, June 2005

1478 Chang Woon Nam and Doina Maria Radulescu, Effects of Corporate Tax Reforms on SMEs' Investment Decisions under the Particular Consideration of Inflation, June 2005

1479 Panos Hatzipanayotou, Sajal Lahiri and Michael S. Michael, Globalization, CrossBorder Pollution and Welfare, June 2005

1480 John Whalley, Pitfalls in the Use of Ad valorem Equivalent Representations of the Trade Impacts of Domestic Policies, June 2005

1481 Edward B. Barbier and Michael Rauscher, Trade and Development in a Labor Surplus Economy, June 2005

1482 Harrie A. A. Verbon and Cees A. Withagen, Tradable Emission Permits in a Federal System, June 2005

1483 Hendrik Hakenes and Andreas Irmen, On the Long-Run Evolution of Technological Knowledge, June 2005

1484 Nicolas Schmitt and Antoine Soubeyran, A Simple Model of Brain Circulation, June 2005

1485 Carsten Hefeker, Uncertainty, Wage Setting and Decision Making in a Monetary Union, June 2005

1486 Ondřej Schneider and Jan Zápal, Fiscal Policy in New EU Member States - Go East, Prudent Man!, June 2005

1487 Christian Schultz, Virtual Capacity and Competition, June 2005 
1488 Yvan Lengwiler and Elmar Wolfstetter, Bid Rigging - An Analysis of Corruption in Auctions, June 2005

1489 Johannes Becker and Clemens Fuest, Does Germany Collect Revenue from Taxing Capital Income?, June 2005

1490 Axel Dreher and Panu Poutvaara, Student Flows and Migration: An Empirical Analysis, June 2005

1491 Bernd Huber and Marco Runkel, Interregional Redistribution and Budget Institutions under Asymmetric Information, June 2005

1492 Guido Tabellini, Culture and Institutions: Economic Development in the Regions of Europe, July 2005

1493 Kurt R. Brekke and Michael Kuhn, Direct to Consumer Advertising in Pharmaceutical Markets, July 2005

1494 Martín Gonzalez-Eiras and Dirk Niepelt, Sustaining Social Security, July 2005

1495 Alfons J. Weichenrieder, (Why) Do we need Corporate Taxation?, July 2005

1496 Paolo M. Panteghini, S-Based Taxation under Default Risk, July 2005

1497 Panos Hatzipanayotou and Michael S. Michael, Migration, Tied Foreign Aid and the Welfare State, July 2005

1498 Agata Antkiewicz and John Whalley, BRICSAM and the Non-WTO, July 2005

1499 Petr Hedbávný, Ondřej Schneider and Jan Zápal, A Fiscal Rule that has Teeth: A Suggestion for a 'Fiscal Sustainability Council' underpinned by the Financial Markets, July 2005

1500 J. Atsu Amegashie and Marco Runkel, Sabotaging Potential Rivals, July 2005

1501 Heikki Oksanen, Actuarial Neutrality across Generations Applied to Public Pensions under Population Ageing: Effects on Government Finances and National Saving, July 2005

1502 Xenia Matschke, Costly Revenue-Raising and the Case for Favoring Import-Competing Industries, July 2005

1503 Horst Raff and Nicolas Schmitt, Why Parallel Trade may Raise Producers Profits, July 2005

1504 Alberto Bisin and Piero Gottardi, Efficient Competitive Equilibria with Adverse Selection, July 2005

1505 Peter A. Zadrozny, Necessary and Sufficient Restrictions for Existence of a Unique Fourth Moment of a Univariate GARCH(p,q) Process, July 2005 
1506 Rainer Niemann and Corinna Treisch, Group Taxation, Asymmetric Taxation and Cross-Border Investment Incentives in Austria, July 2005

1507 Thomas Christiaans, Thomas Eichner and Ruediger Pethig, Optimal Pest Control in Agriculture, July 2005

1508 Biswa N. Bhattacharyay and Prabir De, Promotion of Trade and Investments between China and India: The Case of Southwest China and East and Northeast India, July 2005

1509 Jean Hindriks and Ben Lockwood, Decentralization and Electoral Accountability: Incentives, Separation, and Voter Welfare, July 2005

1510 Michelle R. Garfinkel, Stergios Skaperdas and Constantinos Syropoulos, Globalization and Domestic Conflict, July 2005

1511 Jesús Crespo-Cuaresma, Balázs Égert and Ronald MacDonald, Non-Linear Exchange Rate Dynamics in Target Zones: A Bumpy Road towards a Honeymoon - Some Evidence from the ERM, ERM2 and Selected New EU Member States, July 2005

1512 David S. Evans and Michael Salinger, Curing Sinus Headaches and Tying Law: An Empirical Analysis of Bundling Decongestants and Pain Relievers, August 2005

1513 Christian Keuschnigg and Martin D. Dietz, A Growth Oriented Dual Income Tax, July 2005

1514 Fahad Khalil, David Martimort and Bruno Parigi, Monitoring a Common Agent: Implications for Financial Contracting, August 2005

1515 Volker Grossmann and Panu Poutvaara, Pareto-Improving Bequest Taxation, August 2005

1516 Lars P. Feld and Emmanuelle Reulier, Strategic Tax Competition in Switzerland: Evidence from a Panel of the Swiss Cantons, August 2005

1517 Kira Boerner and Silke Uebelmesser, Migration and the Welfare State: The Economic Power of the Non-Voter?, August 2005

1518 Gabriela Schütz, Heinrich W. Ursprung and Ludger Wößmann, Education Policy and Equality of Opportunity, August 2005

1519 David S. Evans and Michael A. Salinger, Curing Sinus Headaches and Tying Law: An Empirical Analysis of Bundling Decongestants and Pain Relievers, August 2005

1520 Michel Beine, Paul De Grauwe and Marianna Grimaldi, The Impact of FX Central Bank Intervention in a Noise Trading Framework, August 2005

1521 Volker Meier and Matthias Wrede, Pension, Fertility, and Education, August 2005

1522 Saku Aura and Thomas Davidoff, Optimal Commodity Taxation when Land and Structures must be Taxed at the Same Rate, August 2005 
1523 Andreas Haufler and Søren Bo Nielsen, Merger Policy to Promote 'Global Players'? A Simple Model, August 2005

1524 Frederick van der Ploeg, The Making of Cultural Policy: A European Perspective, August 2005

1525 Alexander Kemnitz, Can Immigrant Employment Alleviate the Demographic Burden? The Role of Union Centralization, August 2005

1526 Baoline Chen and Peter A. Zadrozny, Estimated U.S. Manufacturing Production Capital and Technology Based on an Estimated Dynamic Economic Model, August 2005

1527 Marcel Gérard, Multijurisdictional Firms and Governments' Strategies under Alternative Tax Designs, August 2005

1528 Joerg Breitscheidel and Hans Gersbach, Self-Financing Environmental Mechanisms, August 2005

1529 Giorgio Fazio, Ronald MacDonald and Jacques Mélitz, Trade Costs, Trade Balances and Current Accounts: An Application of Gravity to Multilateral Trade, August 2005

1530 Thomas Christiaans, Thomas Eichner and Ruediger Pethig, A Micro-Level 'Consumer Approach' to Species Population Dynamics, August 2005

1531 Samuel Hanson, M. Hashem Pesaran and Til Schuermann, Firm Heterogeneity and Credit Risk Diversification, August 2005

1532 Mark Mink and Jakob de Haan, Has the Stability and Growth Pact Impeded Political Budget Cycles in the European Union?, September 2005

1533 Roberta Colavecchio, Declan Curran and Michael Funke, Drifting Together or Falling Apart? The Empirics of Regional Economic Growth in Post-Unification Germany, September 2005

1534 Kai A. Konrad and Stergios Skaperdas, Succession Rules and Leadership Rents, September 2005

1535 Robert Dur and Amihai Glazer, The Desire for Impact, September 2005

1536 Wolfgang Buchholz and Wolfgang Peters, Justifying the Lindahl Solution as an Outcome of Fair Cooperation, September 2005

1537 Pieter A. Gautier, Coen N. Teulings and Aico van Vuuren, On-the-Job Search and Sorting, September 2005

1538 Leif Danziger, Output Effects of Inflation with Fixed Price- and Quantity-Adjustment Costs, September 2005 